\title{
Cabomba caroliniana Gray (Cabombaceae) invades major waterways in Belgium
}

\author{
Kevin Scheers", Luc Denys, Indra Jacobs, Jo Packet, Vincent Smeekens and Tim Adriaens \\ Research Institute for Nature and Forest (INBO), Havenlaan 88 bus 73, 1000 Brussels, Belgium
}

Received: 8 February 2019 / Accepted: 10 April 2019

\begin{abstract}
Recently, unattached viable stem fragments of the invasive macrophyte Cabomba caroliniana Gray were found at several locations in two canals in northern Belgium. A subsequent survey of the canal Zuid-Willemsvaart revealed one site with rooted plants and the presence of floating stem fragments along the entire length of the canal $(25 \mathrm{~km})$. These findings indicate that $C$. caroliniana is already well established in the Zuid-Willemsvaart and probably considerably more widespread than previous records from isolated lentic water bodies indicate. We have summarised the new records and discuss the potential spread and risks associated with further establishment and spread of C. caroliniana in Belgium.
\end{abstract}

Keywords: fanwort / invasive species / non-native species / alien species / Cabomba

Résumé - Cabomba caroliniana Gray (Cabombaceae) envahit les principales voies navigables en Belgique. Récemment, des fragments de tiges viables libres du macrophyte envahissant Cabomba caroliniana Gray ont été trouvés à plusieurs endroits dans deux canaux du nord de la Belgique. Une étude subséquente du canal Zuid-Willemsvaart a révélé la présence de plantes à racines et de fragments de tiges flottantes sur toute la longueur du canal $(25 \mathrm{~km})$. Ces résultats indiquent que $C$. caroliniana est déjà bien établie dans le Zuid-Willemsvaart et probablement beaucoup plus répandue que les signalements précédents dans des masses d'eau lentiques isolées l'indiquent. Nous avons récapitulé les nouveaux signalements et discuté de la dissémination potentielle et des risques associés à l'établissement et à la dissémination de C. caroliniana en Belgique.

Mots clés : espèces envahissantes / espèces exotiques / espèces exotiques / Cabomba

Cabomba caroliniana Gray is a submerged aquatic plant with a native range from northeast Argentina to the southern and eastern USA (Ørgaard, 1991). The species enjoys longstanding popularity for aquarium culture but behaves invasively in several European, Asian, as well as in parts of the USA, Canada and Oceania (Ørgaard, 1991; ISSG, 2005; EPPO, 2007; Brundu, 2015). As a consequence, C. caroliniana was included on the list of species of EU Concern sensu Regulation (EU) $1143 / 2014$ on the prevention of the introduction and spread of Invasive Alien Species (European Union, 2014). Hence, the species is subject to a ban on trade and possession, and member states are required to actively tackle its pathways of introduction and implement rapid removal or population management. In Europe, $C$. caroliniana is easily recognizable by the petiolated, finely dissected fan-shaped submersed leaves, placed oppositely in pairs with partitions in a single plane. Native species with similar

\footnotetext{
${ }^{*}$ Corresponding author: kevin.scheers@inbo.be
}

fan-shaped leaves, such as certain Ranunculus or Myriophyllum species, have differently arranged submersed leaves. Any confusion is further rendered unlikely in case its typical triangular floating leaves or white flowers develop, a developmental stage rarely reached in European populations.

In Belgium, C. caroliniana was reported only twice, so far, and only from hydrologically isolated, stagnant water sites of limited size where it was probably introduced from aquarium culture. The first record (Denys et al., 2000, 2003; Verloove, 2002) was in an derelict fishpond near Holsbeek, Province Vlaams-Brabant, where a stable population occurred from 1998 up to 2006 when it disappeared following restocking with fish and development of turbid conditions (Scheers et al., 2016). A second occurrence was noted in 2013 near SintPauwels, province Oost-Vlaanderen. Here, C. caroliniana was the dominant hydrophyte in a ditch amidst a residential area (Scheers et al., 2016). Considerable effort was made to eradicate the species at this site, including drawdown and mechanical removal in the summer of 2018 followed by manual removal of remaining fragments and new shoots, at a 


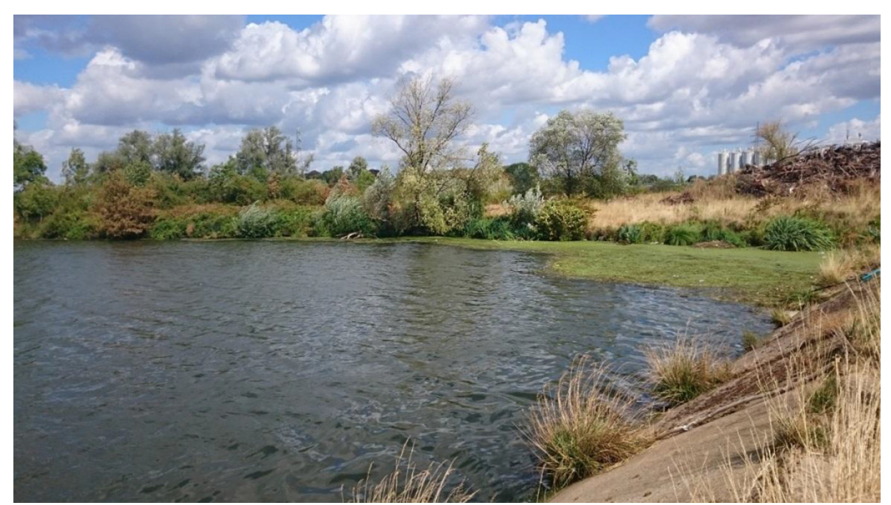

Fig. 1. Zuid-Willemsvaart at Uikhoven, Limburg (N 5055'3.7"; E $\left.5^{\circ} 42^{\prime} 13.2^{\prime \prime}\right), 10$.VIII.2018. At this site several rooted plants and numerous loose fragments of C.caroliniana were present (photo K. Scheers).

total expense of $40 \mathrm{k} €$. Nevertheless, vigorous regrowth occurred and further measures are currently underway to eradicate Cabomba completely at this site (personal communication Koen Van Roeyen, 2018).

In June 2017, two rather small but viable fragments of C. caroliniana were found floating along the bank of the canal Dessel-Turnhout-Schoten near Sint-Lenaarts (province of Antwerp). In August 2018, several fresh stem fragments were also observed in the canal Zuid-Willemsvaart near Neeroeteren (province of Limburg). A subsequent survey in August 2018 along the Zuid-Willemsvaart revealed a single site at Uikhoven where rooting plants frequently occurred over ca. $60 \mathrm{~m}^{2}$. Fragments of several plant species accumulated together with organic and inorganic debris in a sheltered bend of the canal. It is easily envisaged how stem or rhizome fragments of C. caroliniana originating from upstream, could take root at this location. Numerous fanwort fragments were floating at the edge of the debris mass and subject to transport by wash from boats and water currents (Fig. 1). Additionally, unattached viable stem fragments were observed along the entire surveyed length of the canal between Neerharen and Bree, a distance of $25 \mathrm{~km}$ (Fig. 2). The fragments found in the canal DesselTurnhout-Schoten, as well as in the Zuid-Willemsvaart were all viable, ranging in length from 8 to $125 \mathrm{~cm}$. All were sterile but several exposed roots enabling them to swiftly colonize new sites.

Studied material: Sint-Lenaarts, Antwerpen, Kanaal Bochelt-Turnhout-Schoten (N 51²0'16.8"; E 4³9'36"), 30. VI.2017, two loose fragments, leg. I. Jacobs; Neeroeteren, Limburg, Zuid-Willemsvaart (N 5104'11.7"; E 541'52.4"), 06. VIII.2018, several loose fragments, leg. K. Scheers; Neeroeteren, Limburg, Zuid-Willemsvaart (N 51 04'8.5"; E $\left.5^{\circ} 41^{\prime} 52.1 "\right)$, 06.VIII.2018, several loose fragments, leg. K. Scheers; Uikhoven, Limburg, Zuid-Willemsvaart (N 5055'3.7"; E $\left.5^{\circ} 42^{\prime} 13.2^{\prime \prime}\right), 10$.VIII.2018, several rooted plants and numerous loose fragments, leg. K. Scheers; Mechelen-Aan-De-Maas, Limburg, Zuid-Willemsvaart (N 5057'27.5"; E 542'32.3"), 10. VIII.2018, one loose fragment, leg. K. Scheers; Eisden, Limburg, Zuid-Willemsvaart (N 5100'2.2"; E 542'37"), 10. VIII.2018, several loose fragments, leg. K. Scheers; Bree, Limburg, Zuid-Willemsvaart (N 51 07'52.6"; E 5³8'26.1"), 10.

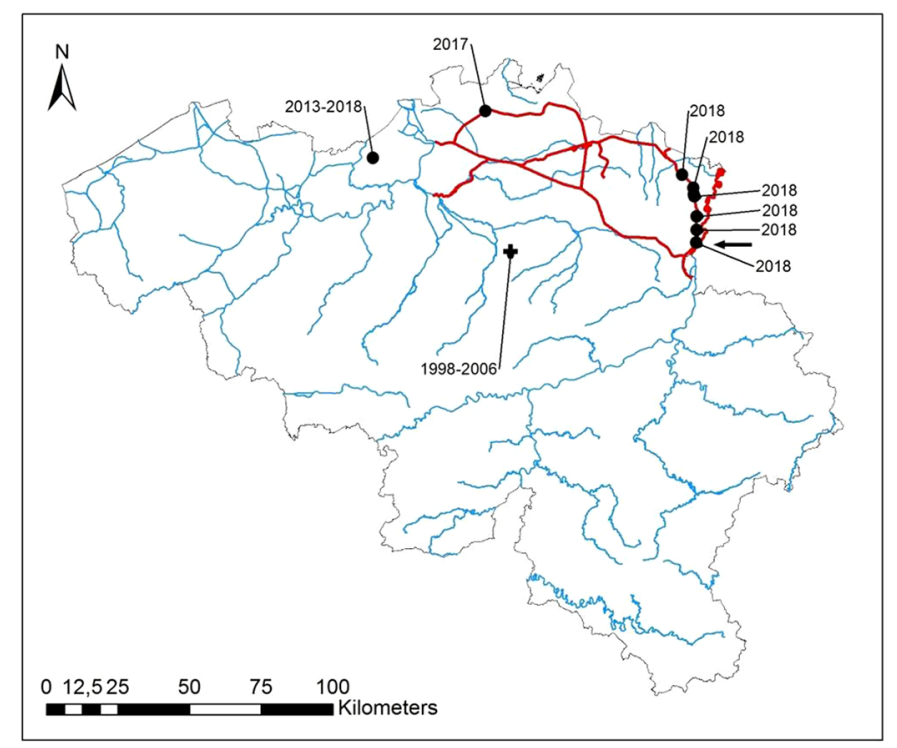

Fig. 2. Distribution map of Cabomba Caroliniana in Belgium with first and last year of sighting. The black cross-indicates a former population, black dots represent new records with the arrow indicating the site with rooted plants at Uikhoven. In blue: major rivers and canals, in red: connected lentic and lotic habitats most at risk.

VIII.2018, several loose fragments, leg. K. Scheers; Uikhoven, Limburg, Zuid-Willemsvaart (N 5055'3.7"; E 542'13.2"), 09. IX.2018, several rooted plants and numerous loose fragments, leg. V. Smeekens; Neeroeteren, Limburg, Zuid-Willemsvaart (N 51 ${ }^{\circ} 05^{\prime} 21.9^{\prime \prime}$; E 5 41'40.4"), 10.IX.2018, one loose fragment, leg. K. Scheers; Uikhoven, Limburg, Zuid-Willemsvaart (N 5055'3.7"; E 542'13.2"), 09.X.2018, several rooted plants and numerous loose fragments, leg. K. Scheers.

Considering the widespread and locally problematic occurrence of C. caroliniana in The Netherlands (Matthews et al., 2013), the small number of records in Belgium - only two sites in almost 15 years - up to the last few years is striking. Based on the isolated character of these colonies, one of which disappeared without targeted control measures, the more scattered occurrence of potential habitat and the generally much lower hydrological connectivity of water bodies compared to The Netherlands, Scheers et al. (2016) considered the risk of $C$. caroliniana becoming widespread in Belgium as rather low. This was prior to any observations in waterways, however, and only considered punctual, unrelated introductions. Introduction and establishment of the species in the canal network crossing northern Belgium is a game changer. Although separate introductions in both canals cannot be excluded, it is more likely that the spread of these loose fragments was enabled by sluicing and wash from commercial shipping and recreational boating.

The finds in the canal Dessel-Schoten and the ZuidWillemsvaart come quite unexpected. The aquatic vegetation of the Dessel-Schoten canal was surveyed in 2007, in search of Myriophyllum heterophyllum Michaux, without any record of C.caroliniana (De Beer and De Vlaeminck, 2008). We assume the species arrived here later. Except one, all records in the Zuid-Willemsvaart, as well as that in the 
canal Dessel-Turnhout-Schoten, concerned loose plant fragments. The site of Uikhoven is at c. $26 \mathrm{~km}$ from the most upstream observation in the same canal. Both canals are connected by the canal Bochelt-Herentals, but the most proximate observations in both are still c. $86 \mathrm{~km}$ apart or even $112 \mathrm{~km}$, if only Uikhoven is considered. Although fanwort can survive free-floating for six to eight weeks (Australian Department of the Environment and Heritage, 2003), it seems likely that there must be more than one rooting population involved to explain the almost simultaneous occurrence of fragments at all sites. C. caroliniana spreads by means of rhizome or stem fragments that root easily (Mikulyuk and Nault, 2015) and we suspect the presence of multiple established populations, at least in the Zuid-Willemsvaart canal and possibly also in the canals of Dessel-Schoten and Bocholt-Herentals. Due to the size of these canals and the limited accessibility of parts where submerged vegetation may develop, in particular fanwort which may grow up to several metre deep and in turbid water, these will be difficult to detect. A more targeted survey of the Zuid-Willemsvaart and other canals, as well as of lentic water bodies receiving water from them, is definitely required to document the precise distribution of C. carolinana in Belgium. We estimate that at least $387 \mathrm{~km}$ of connected waterways and 755 ha of gravel and sand pits could provide potential habitat for the species (Fig. 2). Some of the latter are partly included in special conservation areas or could provide easy access to areas of high conservation value for aquatic biodiversity. The river Meuse and several sand and gravel pits connected to these canals accommodate the Natura 2000 habitat types 3130,3150 or 3260 as defined in the Habitats Directive.

The question remains how fanwort entered the Belgian canal network. Whilst previous introductions can be attributed to dumped aquarium plants, the most likely explanation in this case seems colonization of the Zuid-Willemsvaart by stem fragments from the river Meuse, from which it receives its water, and subsequent spread to the canal Dessel-Turnhout-Schoten. $C$. caroliana is known to occur in the Border Meuse since 1986 (van Valkenburg and Rotteveel, 2010) and floating fragments have been found along the Dutch bank, upstream as well as downstream of its connection to the Zuid-Willemsvaart (De Vries, 2018). Surveys in the Belgian part of the Border Meuse, however, never revealed C.caroliniana. Whether C.caroliniana also occurs further upstream in the Meuse, in the Walloon region or, perhaps, even in France, remains unknown.

C. caroliniana is included in the Union List of Regulation (EU) $1143 / 2014$, therefore the feasibility of eradicating the newly discovered population needs to be evaluated based on the currently available methods, their effectiveness, costs and other risk management considerations (Booy et al., 2017).

Because C. caroliniana has now entered navigable waterways of considerable size and economic importance, its complete eradication in lower Belgium seems to have become very unlikely. None of the more efficient and commonly used eradication methods for invasive macrophytes (Drolet et al., 2014) or C. caroliniana in particular (Scheers et al., 2016; Hussner et al., 2017) appear suited for these conditions. A dedicated survey for C.caroliniana, including less easily accessible parts and areas adjacent to the canal, is necessary to guide any decision on managing this invasive species and to evaluate options for limiting its spread or mitigating associated risk or impact.

Acknowledgements. Thanks to Koen Van Roeyen for keeping us up to date on the situation at the Sint-Pauwels site. Furthermore, thanks are due two anonymous reviewers for their valuable comments and Will Watson (Leominster, UK) who improved the language of the manuscript.

\section{References}

Australian Department of the Environment and Heritage. 2003. Cabomba (Cabomba caroliniana). Weeds of National Significance: Weed Management Guide Department of the Environment and Heritage and the CRC for Australian Weed Management. http:// www.environment.gov.au (accessed 13 August 2018).

European Union. 2014. Regulation (EU) no. 1143/2014 of the European parliament and of the Council of 22 October 2014 on the prevention and management of the introduction and spread of invasive alien species. Official J European Union L317: 35-55.

Booy O, Mill AC, Roy HE, et al. 2017. Risk management to prioritise the eradication of new and emerging invasive non-native species. Biol Invasions 19(8): 2401-2417. DOI: https://doi.org/10.1007/ s10530-017-1451-z.

Brundu G. 2015. Plant invaders in European and Mediterranean inland waters: profiles, distribution, and threats. Hydrobiologia 746: 61-79. DOI: http://dx.doi.org/10.1007/s10750-014-1910-9.

De Beer D, De Vlaeminck R. 2008. Myriophyllum heterophyllum, een nieuwe invasieve waterplant. Dumortiera 94: 8-13.

Denys L, Moons V, Veraart B, eds. 2000. Ecologische typologie en onderzoek naar een geïntegreerde evaluatiemethode voor stilstaande wateren op regionale schaal: hoekstenen voor ontwikkeling, herstel en opvolging van natuurwaarden. Eindverslag VLINA 97/02. Departement Biologie, Universiteit Antwerpen, Antwerp and Instituut voor Natuurbehoud, Brussels.

Denys L, Packet J, Weiss L, Coenen M. 2003. Cabomba caroliniana (Cabombaceae) houdt stand in Holsbeek (Vlaams-Brabant, België). Dumortiera 80: 35-40.

De Vries H. 2018. Observation.org, Nature data from the Netherlands. Observation.org. Occurrence dataset. https://doi.org/10.15468/ 5nilie accessed via GBIF.org on 2019-04-05. https://www.gbif. org/occurrence/1960842937.

Drolet D, Locke A, Lewis M, Davidson J. 2014. User-friendly and evidence-based tool to evaluate probability of eradication of aquatic non-indigenous species. J Appl Ecol 51: 1050-1056. DOI: http://dx.doi.org/10.1111/1365-2664.12263.

EPPO. 2007. Pest risk analysis for Cabomba caroliniana Gray. http:// www.eppo.int (accessed 13 August 2018).

Hussner A, Stiers I, Verhofstad MJJM, Bakker ES, Grutters BMC, Haury J, van Valkenburg JLCH, Brundu G, Newman J, Clayton JS, Anderson LWJ, Hofstra D. 2017. Management and control methods of invasive alien freshwater aquatic plants: a review. Aquat Bot 136: 112-136.

ISSG. 2005. Global Invasive Species Database (GISD). Auckland, New Zealand: University of Auckland. http://www.issg.org/ database (accessed 13 August 2018).

Matthews J, Beringen R, Lamers LPM, Odé B, Pot R, van der Velde G, van Valkenburg LLCH, Verbrugge LNH, Leuven RSEW. 2013. Knowledge document for risk analysis of the non-native Fanwort 
K. Scheers et al:: Knowl. Manag. Aquat. Ecosyst. 2019, 420, 22

(Cabomba caroliniana) in the Netherlands. Radboud University Nijmegen. Reports Environmental Science nr. 443, 60 p.

Mikulyuk A, Nault M. 2015. CABI Invasive Species Compendium datasheet. Cabomba caroliniana. http://sites.cabi.org (accessed 13 August 2018).

Ørgaard M. 1991. The genus Cabomba (Cabombaceae) - a taxonomic study. Nord J Bot 11: 179-203. DOI: http://dx.doi. org/10.1111/j.1756-1051.1991.tb01819.x.
Scheers K, Denys L, Packet J, Adriaans T. 2016. A second population of Cabomba caroliniana Gray (Cabombaceae) in Belgium with options for its eradication. Bioinvasions Rec 5: 227-232. DOI: http://dx.doi.org/10.3391/bir.2016.5.4.06.

van Valkenburg JLCH, Rotteveel AJW. 2010. Cabomba caroliniana Gray, een tropische verrassing in Loosdrecht. Gorteria 34: 106-118.

Verloove F. 2002. Ingeburgerde plantensoorten in Vlaanderen. Mededeling van het Instituut voor Natuurbehoud 20, 227 p.

Cite this article as: Scheers K, Denys L, Jacobs I, Packet J, Smeekens V, Adriaens T. 2019. Cabomba caroliniana Gray (Cabombaceae) invades major waterways in Belgium. Knowl. Manag. Aquat. Ecosyst., 420, 22. 